\title{
Wood-Derived Black Carbon (Biochar) as a Microbial Electron Donor and Acceptor
}

\author{
Jovita M. Saquing ${ }^{l}$, Yu-Han $\mathrm{Yu}^{l, 2}$ and Pei C. Chiu ${ }^{l *}$ \\ ${ }^{1}$ Department of Civil and Environmental Engineering, University of Delaware, Newark, DE 19716, USA \\ ${ }^{2}$ Department of Environmental Engineering, National Chung-Hsing University, Taichung 40227, Taiwan \\ ${ }^{*}$ Corresponding Author Email: pei@udel.edu \\ Phone: +1 (302) 831-3104 \\ Fax: $+1(302) 831-3640$
}

\section{Summary (10 pages; 2 tables; 2 figures)}

This supporting information contains 2 tables listing biochar and rinsate properties, a description of the sampling and analytical methods used and cell density estimation, calculations of biochar's electron storage capacity based on acetate oxidation or nitrate reduction, a figure showing nitrate reduction to nitrite and ammonium with acetate and microbially reduced biochar as electron donor, and an SEM image of washed biologically reduced biochar from an acetate utilization experiment. 
Table S1. Physical-chemical properties of Soil Reef biochar

\begin{tabular}{|c|c|c|c|}
\hline & Value $^{\mathrm{a}}$ & Units & Method \\
\hline $\mathrm{pH}$ & $8.71^{\mathrm{b}}$ & & $1: 20 \mathrm{w} / \mathrm{v}$ in DI water, $24 \mathrm{hr}$ \\
\hline Electrical Conductivity (EC 20 & & & \\
\hline $\mathrm{w} / \mathrm{w})$ & 283 & mmhos $\mathrm{cm}^{-1}$ & 4.11 USCC:dil. Rajkovich \\
\hline Total Ash & 21.4 & $\%$ of total mass & ASTM D-1762-84 \\
\hline Particle Density & $1.816^{\mathrm{b}}$ & $\mathrm{g} \mathrm{cm}^{-3}$ & \\
\hline BET Surface Area & $391 \pm 10^{b}$ & $\mathrm{~m}^{2} \mathrm{~g}^{-1}$ & $\mathrm{~N}_{2}$ adsorption \\
\hline Organic Carbon (org-C) & 74.2 & $\%$ of total mass & Dry Combustion-ASTM 4373 \\
\hline Total Nitrogen $(\mathrm{N})$ & 0.59 & $\%$ of total mass & Dry Combustion-ASTM 4373 \\
\hline Hydrogen/Carbon (H/C) Ratio & 0.26 & & Dry Combustion-ASTM 4374 \\
\hline Liming (neutral value as $\mathrm{CaCO}_{3}$ ) & 14.7 & $\% \mathrm{CaCO}_{3}$ & Rayment \& Higinson \\
\hline Total Potassium $(\mathrm{K})$ & 3566 & $\mathrm{mg} / \mathrm{Kg}$ dry mass & Enders \& Lehman \\
\hline Available K & 4034 & $\mathrm{mg} / \mathrm{Kg}$ dry mass & Wang after Rajan \\
\hline Total Phosphorous(P) & 2528 & $\mathrm{mg} / \mathrm{Kg}$ dry mass & Enders \& Lehman \\
\hline Available $\mathrm{P}$ & 1608 & $\mathrm{mg} / \mathrm{Kg}$ dry mass & Wang after Rajan \\
\hline Total N & 0.59 & $\mathrm{mg} / \mathrm{Kg}$ dry mass & $\mathrm{KjN}$ \\
\hline Ammonia $\left(\mathrm{NH}_{4}-\mathrm{N}\right)$ & 4.1 & $\mathrm{mg} / \mathrm{Kg}$ dry mass & Rayment \& Higinson \\
\hline Nitrate $\left(\mathrm{NO}_{3}-\mathrm{N}\right)$ & 63 & $\mathrm{mg} / \mathrm{Kg}$ dry mass & Rayment \& Higinson \\
\hline Organic (Org-N) & 5800 & $\mathrm{mg} / \mathrm{Kg}$ dry mass & \\
\hline Volatile Matter & 79 & $\%$ dry mass & ASTM D-1762-84 \\
\hline Arsenic (As) & 1.4 & $\mathrm{mg} / \mathrm{Kg}$ dry mass & EPA 3050B/EPA 6010 \\
\hline Cadmium (Cd) & $<0.01$ & $\mathrm{mg} / \mathrm{Kg}$ dry mass & EPA 3050B/EPA 6010 \\
\hline Chromium (Cr) & 11 & $\mathrm{mg} / \mathrm{Kg}$ dry mass & EPA 3050B/EPA 6010 \\
\hline Cobalt $(\mathrm{Co})$ & 1.3 & $\mathrm{mg} / \mathrm{Kg}$ dry mass & EPA 3050B/EPA 6010 \\
\hline Copper $(\mathrm{Cu})$ & 24 & $\mathrm{mg} / \mathrm{Kg}$ dry mass & EPA 3050B/EPA 6010 \\
\hline Lead $(\mathrm{Pb})$ & 3 & $\mathrm{mg} / \mathrm{Kg}$ dry mass & EPA 3050B/EPA 6010 \\
\hline Molybdenum (Mo) & 0.22 & $\mathrm{mg} / \mathrm{Kg}$ dry mass & EPA 3050B/EPA 6010 \\
\hline Mercury (Hg) & $<0.2$ & $\mathrm{mg} / \mathrm{Kg}$ dry mass & EPA 7471 \\
\hline Nickel (Ni) & 5.1 & $\mathrm{mg} / \mathrm{Kg}$ dry mass & EPA 3050B/EPA 6010 \\
\hline Selenium (Se) & $<0.3$ & $\mathrm{mg} / \mathrm{Kg}$ dry mass & EPA 3050B/EPA 6010 \\
\hline Zinc $(\mathrm{Zn})$ & 15 & $\mathrm{mg} / \mathrm{Kg}$ dry mass & EPA 3050B/EPA 6010 \\
\hline Boron (B) & 40 & $\mathrm{mg} / \mathrm{Kg}$ dry mass & TMECC \\
\hline Chlorine $(\mathrm{Cl})$ & 325 & $\mathrm{mg} / \mathrm{Kg}$ dry mass & TMECC \\
\hline Sodium $(\mathrm{Na})$ & 465 & $\mathrm{mg} / \mathrm{Kg}$ dry mass & EPA 3050B/EPA 6010 \\
\hline
\end{tabular}

${ }^{a}$ Data provided by The Biochar Company unless otherwise noted.

${ }^{b}$ Measured at the University of Delaware. 
Table S2. Dissolved organic carbon in biochar rinsate/filtrate

\begin{tabular}{lccccc}
\hline & Batch $^{\mathbf{a}}$ & \multicolumn{2}{c}{ TOC (mg/L) } & $\begin{array}{c}\text { DOC content } \\
\text { (mg/g biochar) }\end{array}$ & $\begin{array}{c}\text { EEC }^{\mathbf{b}} \\
\text { (mmol e } / \mathbf{g} \text { biochar) }\end{array}$ \\
\hline First Rinsate & $\mathrm{A}$ & 32.9 & 1.7 & 0.66 & 0.0022 \\
& $\mathrm{~B}$ & 32.9 & 0.8 & 0.66 & 0.0022 \\
& $\mathrm{C}$ & 42.1 & 0.9 & 0.84 & 0.0028 \\
\hline Second Rinsate & & & & & 0.0019 \\
& $\mathrm{~A}$ & 28.3 & 2.4 & 0.57 & 0.0019 \\
& $\mathrm{~B}$ & 28.6 & 0.8 & 0.57 & 0.0028 \\
\hline Vacuum Filtrate & $\mathrm{C}$ & 42.1 & 0.9 & 0.84 & \\
& & & & & 0.0010 \\
& $\mathrm{~A}$ & 15.5 & 1.2 & 0.31 & 0.0014 \\
& $\mathrm{~B}$ & 20.2 & 1.9 & 0.40 & 0.0010 \\
\hline
\end{tabular}

${ }^{\mathrm{a}}$ Each batch contained $50 \mathrm{~g}$ of sieved biochar washed and aerated in $1 \mathrm{~L}$ of deionized water. ${ }^{b}$ Electron exchange capacity calculated using the carbon content $(0.581)$ and electron capacity of Elliott soil humic acid (1.96 mmol/g humic acid), which had the highest electron capacity of all the humic and fulvic acids studied by Aeschbacher et al. ${ }^{1}$ 


\section{Sampling Procedures, Analytical Methods, and Cell Density Estimation}

Liquid samples for acetate, nitrite, nitrate and ammonium measurement were collected at various elapsed times during the course of each batch experiment. Sample collection from serum bottles was carried out under a verified protocol to preclude microbial and oxygen contamination. The rubber stopper of each bottle was sterilized with $70 \%$ ethanol before sampling. All glass syringes and disposable needles for sampling were flushed with $\mathrm{N}_{2} / \mathrm{CO}_{2}(80: 20)$ multiple times before use. One $\mathrm{mL}$ of liquid sample was drawn and diluted 10 fold with deionized water in a $10-\mathrm{mL}$ volumetric flask. After mixing the diluted sample was immediately filtered with $0.22-\mu \mathrm{m}$ syringe filter (MCE, Millex GS) and transferred into 2 vials: $1.5 \mathrm{~mL}$ for $\mathrm{NH}_{4}{ }^{+}$analysis and $8 \mathrm{~mL}$ for anion analysis. Samples were analyzed for anions using an ion chromatograph (IC) immediately after sampling. Samples for $\mathrm{NH}_{4}{ }^{+}$measurements were sealed immediately and stored at $4{ }^{\circ} \mathrm{C}$, and analyzed at the end of each experiment. $\mathrm{NH}_{4}{ }^{+}$standards were made in parallel using the same preparation methods and storage conditions for quality control, which showed no contamination or loss of $\mathrm{NH}_{4}^{+}$during storage.

Acetate, nitrite and nitrate analyses were performed using a Metrohm 850 Professional IC AnCat unit equipped with a conductivity detector. The mobile phase was a mixture of Metrohm MPak A Supp $5(3.2 \mathrm{mM}$ sodium carbonate, $1.0 \mathrm{mM}$ sodium bicarbonate) and $6.5 \% \mathrm{v} / \mathrm{v}$ acetone at a total flow rate of $0.7 \mathrm{~mL} / \mathrm{min}$. The column oven temperature was constant at $28{ }^{\circ} \mathrm{C}$. Ammonium was measured using a Dionex IC (ICS-1100) equipped with an Ion PAC CS16 (5 x $250 \mathrm{~mm})$ and a conductivity detector. The mobile phase was $38 \mathrm{mN}$ sulfuric acid at $1 \mathrm{~mL} / \mathrm{min}$. Concentrations of acetate, nitrite, nitrate, and ammonium were obtained based on calibration curves constructed using $0.1-1.0 \mathrm{mM}$ standard solutions of ammonium chloride, sodium acetate, sodium nitrate, and 
sodium nitrite, individually prepared for each analyte. For quality control, calibration standards were included during IC analysis of each batch of experimental samples.

GS-15 cells used for inoculation in each experiment were freshly grown on acetate and nitrate. After an 18 -h incubation at $30{ }^{\circ} \mathrm{C}$, cells was centrifuged at $1100 \mathrm{~g}$ for $15 \mathrm{~min}$, washed 4 times with an anoxic medium $\left(\mathrm{N}_{2} / \mathrm{CO}_{2}\right.$-purged ATCC 1768 medium minus electron donor, electron acceptor, and $\left.\mathrm{NH}_{4}{ }^{+}\right)$and re-suspended to a density of $7.0( \pm 1.6) \times 10^{9}$ cells $/ \mathrm{mL}$ for inoculation. To obtain cell density, cell suspensions were diluted four-fold for optical density (OD) measurement at $600 \mathrm{~nm}$. The $\mathrm{OD}_{600}$ readings for all cell suspensions were $0.433 \pm 0.072$. Each $\mathrm{OD}_{600}$ reading was converted into a cell density based on McFarland turbidity standards ${ }^{2}$ 1, 2 and 3, which have the apparent absorbance of $0.257,0.451$, and 0.582 and the corresponding cell densities of 3,6 , and $9 \times 10^{8} \mathrm{CFU} / \mathrm{mL}$, respectively. For each experiment, $3 \mathrm{~mL}$ of the cell suspension was added to each reactor and biotic control ( $104 \mathrm{~mL}$ total) to achieve a cell concentration of $\sim 2 \times 10^{8}$ cells $/ \mathrm{mL}$. 


\section{Calculations of Biochar Electron Storage Capacity}

\section{ESC based on acetate utilization in $2 \mathrm{~g}$ air-oxidized biochar bioreactors (Figure 1):}

a) Electrons released by acetate (assuming oxidized fully to $\mathrm{CO}_{2}$, releasing $8 \mathrm{e}^{-}$per molecule) $=($ acetate concentration decrease $) \times$ solution volume $\times\left(\right.$ number of $\mathrm{e}^{-}$per acetate $) \div$biochar mass $=(3.639-1.797) \mathrm{mM} \times 0.104 \mathrm{~L} \times 8 \mathrm{e}^{-} /$acetate $\div 2 \mathrm{~g}$ biochar $=0.766 \mathrm{mmol} \mathrm{e} / \mathrm{g}$ biochar

b1) Electrons provided by cysteine and inoculated cells combined, based on nitrate losses in the cell-only control in Figure 2(a) (assuming reduced fully to $\mathrm{NH}_{4}{ }^{+}$, accepting $8 \mathrm{e}^{-} /$nitrate) $=($ nitrate concentration decrease $) \times$ solution volume $\times\left(\right.$ number of $\mathrm{e}^{-}$per nitrate $) \div$biochar mass $=(4.156-3.274) \mathrm{mM} \times 0.104 \mathrm{~L} \times 8 \mathrm{e}^{-} /$nitrate $\div 2 \mathrm{~g}=0.367 \mathrm{mmol} \mathrm{e} / \mathrm{g}$

b2) Electrons donated by cysteine and inoculated cells combined, based on $\mathrm{NH}_{4}{ }^{+}$formation in the cell-only control

$=\left(\mathrm{NH}_{4}{ }^{+}\right.$concentration increase $) \times$solution volume $\times\left(\right.$number of $\mathrm{e}^{-}$per $\left.\mathrm{NH}_{4}{ }^{+}\right) \div$biochar mass $=(0.208-0) \mathrm{mM} \times 0.104 \mathrm{~L} \times 8 \mathrm{e}^{-} / \mathrm{NH}_{4}{ }^{+} \div 2 \mathrm{~g}=0.173 \mathrm{mmol} \mathrm{e}^{-} \div 2 \mathrm{~g}=0.087 \mathrm{mmol} \mathrm{e} / \mathrm{g}$ All acetate, nitrate, and ammonium concentrations above are averages from triplicate reactors.

Thus, 1) based on nitrate losses, the ESC of the biochar $=\mathrm{a}+\mathrm{b} 1=1.133 \mathrm{mmol} \mathrm{e} / \mathrm{g}$ biochar, and 2) based on $\mathrm{NH}_{4}{ }^{+}$formation, the ESC of the biochar $=\mathrm{a}+\mathrm{b} 2=0.853 \mathrm{mmol} \mathrm{e} / \mathrm{g}$ biochar. While nitrate was reduced by GS-15 to $\mathrm{NH}_{4}{ }^{+}$at high yields in the presence of sufficient electron donors (acetate or reduced biochar, Figure $\mathrm{S} 1), \mathrm{NH}_{4}{ }^{+}$yields were always low $(<30 \%)$ under electronlimited conditions; e.g., $24 \%(=0.087 / 0.367)$ in the cells-only control above. It therefore appears that the nitrate removed from water (e.g., taken up by cells) was reduced only to a limited extent in the controls. We propose the value based on $\mathrm{NH}_{4}^{+}$yields, $\mathbf{0 . 8 5 3} \mathbf{~ m m o l ~} \mathbf{e}^{-} / \mathbf{g}$, would be a better 
estimate of the ESC of this biochar. Also based on $\mathrm{NH}_{4}{ }^{+}$yields the minimum amount of electrons carried by cells in each reactor $=\left(\mathrm{e}^{-}\right.$in $\mathrm{NH}_{4}{ }^{+}-\mathrm{e}^{-}$from cysteine $)=(0.173 \mathrm{mmol}-0.158 \mathrm{mmol})=$ $0.015 \mathrm{mmol} \mathrm{\textrm {e } ^ { - }}$.

\section{ESC based on nitrate reduction to $\mathrm{NH}_{4}{ }^{+}$with $2 \mathrm{~g}$ of dithionite-reduced biochar (Figure 2(b)):}

a1) ESC of the biochar, based on nitrate losses in Figure 2(b) (assuming reduced fully to $\mathrm{NH}_{4}{ }^{+}$, gaining $8 \mathrm{e}^{-}$per nitrate ion)

$=($ nitrate loss in reduced biochar + cells reactors - nitrate loss in cell-only control $) \times$ solution volume $\times\left(\right.$ number of $\mathrm{e}^{-}$per nitrate $) \div$biochar mass

$=(3.138-1.389) \mathrm{mM} \times 0.104 \mathrm{~L} \times 8 \mathrm{e}^{-} /$nitrate $\div 2 \mathrm{~g}$ biochar $=0.728 \mathrm{mmol} \mathrm{e}^{-} / \mathrm{g}$ biochar

a2) ESC of the biochar, based on $\mathrm{NH}_{4}{ }^{+}$production in Figure 2(b) $\left(8 \mathrm{e}^{-}\right.$transferred per $\mathrm{NH}_{4}{ }^{+}$ion $)$

$=\left(\mathrm{NH}_{4}{ }^{+}\right.$formed in reduced biochar+cells reactors $-\mathrm{NH}_{4}{ }^{+}$formed in cell-only control $) \times$solution volume $\times\left(\right.$ number of $\mathrm{e}^{-}$per $\left.\mathrm{NH}_{4}{ }^{+}\right) \div$biochar mass

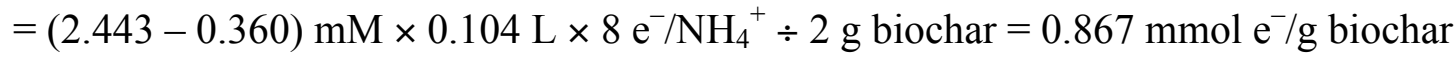

The nitrate and ammonium concentrations above are averages from triplicate reactors.

No cysteine was added to these reactors and control.

The higher ESC based on $\mathrm{NH}_{4}{ }^{+}$production was due mainly to the lower $\mathrm{NH}_{4}{ }^{+}$yield $(0.360 / 1.389$ $=25.9 \%)$ in the cells-only control than in the reduced biochar+cells reactors $(2.443 / 3.138=$ $78.0 \%$ ). Thus, the nitrate lost from solution was reduced only to a limited extent in the cells-only control, as noted earlier. We thus suggest the value based on $\mathrm{NH}_{4}{ }^{+}$production, $\mathbf{0 . 8 6 7} \mathbf{~ m m o l ~} \mathbf{e}^{-} / \mathbf{g}$, would be a more accurate estimate of the ESC of this biochar. This ESC value is also in better agreement with that $\left(\mathbf{0 . 8 5 3} \mathbf{~ m m o l ~} \mathbf{e}^{-} / \mathbf{g}\right)$ obtained based on acetate utilization and $\mathrm{NH}_{4}{ }^{+}$yields. 

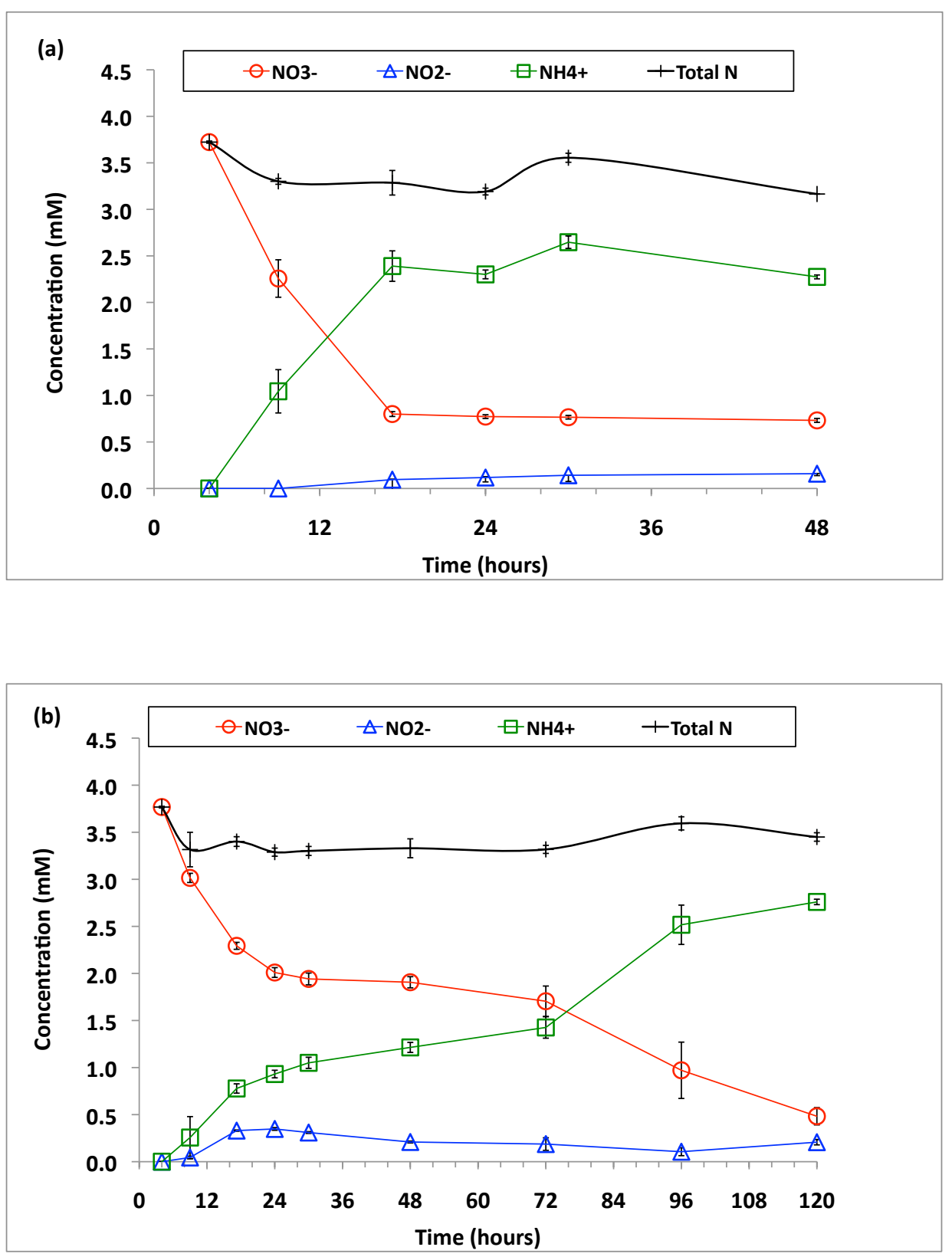

Figure S1. Concentration profiles of nitrate, nitrite, ammonium, and total nitrogen during nitrate reduction by GS-15 with (a) acetate and (b) biologically reduced biochar as electron donor. The final ammonium yields were $70.0 \%$ and $79.6 \%$, respectively. 


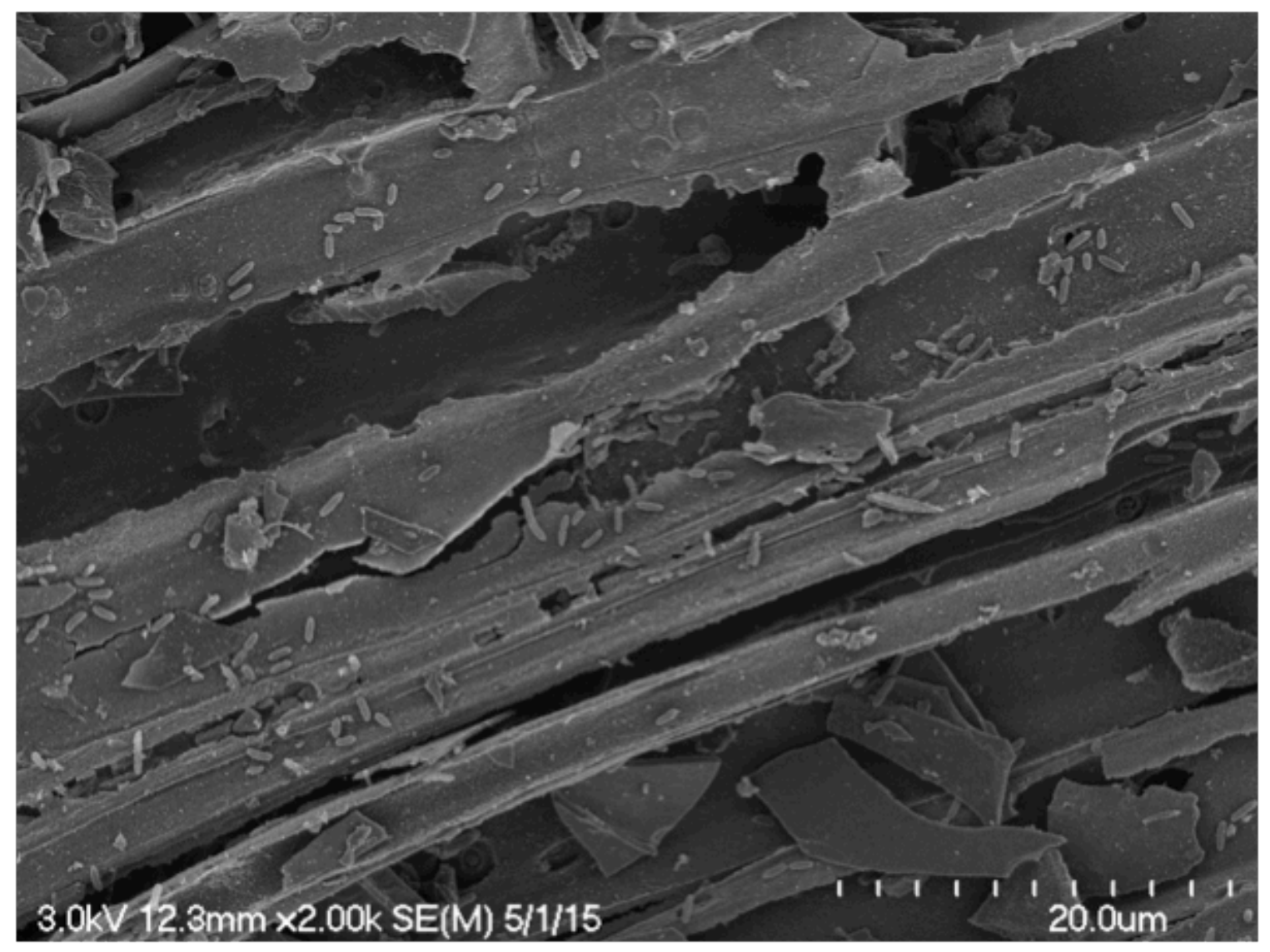

Figure S2. SEM micrograph of thoroughly washed biochar from an acetate oxidation experiment, illustrating attachment of residual GS-15 cells to the surface of biochar. 


\section{References}

(1) Aeschbacher, M.; Sander, M.; Schwarzenbach, R. P. Novel electrochemical approach to assess the redox properties of humic substances. Environ. Sci. Technol. 2010, 44, 87-93.

(2) Sutton, S. Measurement of microbial cells by optical density. Journal of Validation Technology. 2011, 17, 46-49. 